\title{
A NEW GUIDANCE LAW FOR A TACTICAL SURFACE-TO-SURFACE MISSILE
}

\author{
Ćuk V. Danilo, University of Belgrade, Faculty of \\ Mechanical Engineering, Department for Weapon Systems, \\ Belgrade, \\ Abobaker H. S. Mostafa, University of Azawia, Faculty of \\ Engineering, Aeronautical Department, Azawia, Libya, \\ Mandić D. Slobodan, Ministry of Defence, \\ Military Technical Institute, Division for Rocket \\ Dynamics, Belgrade
}

FIELD: Aeronautical and Space Engineering
ARTICLE TYPE: Original Scientific Paper

Summary:

Modern tactical surface-to-surface missiles, equipped with strapdown inertial navigation systems, achieve very good accuracy compared with free-flight rockets. The probable range dispersion mainly depends on instruments errors and longitudinal disturbances such as rocket motor total-impulse deviation as well as differences between the estimated and actual values of the axial force and head wind. This paper gives an extension of the correlated velocity concept for surface-to-surface missiles without a thrust-terminating mechanism. The calculated parameters of the correlated velocity are stored into the memory of an onboard guidance computer. On the basis of the correlated velocity concept, the modified proportional navigation with the adjustment of the time-to-go of the missile to the target was proposed. It is shown that the new guidance law can compensate for the longitudinal disturbances of different levels successfully. The effectiveness of the proposed guidance method was confirmed by means of the calculated probable range and lateral dispersion for the anticipated disturbances in the guidance system.

Key words: Guidance Law, Surface-to-Surface Missile, Correlated Velocity, Proportional Navigation,"Six-Degree-Of-Freedom" Model.

\section{Introduction}

Eree flight rockets exhibit high impact point dispersion at ranges lo-

Fnger than $50 \mathrm{~km}$. The range accuracy of $1 \%$ is possible for free flight rockets using modern technologies, but this performance cannot be accepted even for the area weapons with a range of $120 \mathrm{~km}$. A more significant improvement in accuracy is achieved if the rocket is equipped with 
an appropriate guidance and control system. The different control systems for a rocket with a range of $120 \mathrm{~km}$ were studied in Ref. 1. It was shown that the rocket with a strapdown inertial navigation system (SDINS) and a flight path angle control system can easily attain the circular error probable of 4 mils for the total-impulse tolerances of $\pm 2 \%$. Depending on the totalimpulse deviation, the prescribed values for the velocity vector angle should be corrected with an appropriate function. This is a disadvantage of the method because the correction of the flight path angle was defined by the author through the computation by trial and error.

The nominal trajectory tracking control law was applied in Ref. 2 for a direct fire short range rocket to reduce impact point dispersion using a lateral pulse jet control mechanism. This method was also used in Ref. 3 to improve accuracy of artillery rockets with a range of about $28 \mathrm{~km}$. The other guidance laws applied to a direct fire rocket such as proportional navigation and parabolic and proportional navigation guidance have been studied in Ref. 4. A low cost guidance for a multiple launch rocket system was described in Ref. 5 with a goal to attain the required accuracy for both area and point-hit rockets. In the vertical plane, flight path steering and instantaneous impact point prediction was applied. A proportional navigation method was implemented to eliminate lateral errors. The impact point dispersion was reduced to a level lower than 4 mils at a range of $49.5 \mathrm{~km}$.

In the case of a surface-to-surface missile (SSM) with SDINS, the dominant errors are total-impulse deviations, thrust and aerodynamic misalignment, inertial sensors errors (scale factor and bias errors), mal-launch, initial conditions (position and alignment), target location errors, wind and density disturbances, and aerodynamic coefficients deviations (axial and normal force errors). It was shown in Ref. 1 that disturbances in a cross-flow plane (for example, thrust and aerodynamic misalignment, or side wind) can be compensated successfully. This does not apply to disturbances acting in the longitudinal axis (total-impulse deviations, axial force differences, and head wind). The dispersion of unguided artillery rockets with extended range has been studied in Ref. 6.

The modifications of proportional navigation guidance for the application to a cannon-launched projectile and a gyro-stabilized projectile were presented in Refs. 7 and 8, respectively.

The purpose of this paper is to study a new guidance law for SSM with SDINS in terms of their ability to cope with longitudinal disturbances. Therefore, the concept of the correlated velocity, given in Refs. 9 and 10, will be extended for a missile without a thrust-terminating mechanism. The obtained data are fed into the guidance law to generate a demanded acceleration. The new guidance method, named here the correlated velocity proportional navigation guidance (CV PNG), is analyzed using a probable range and lateral dispersions as well as the maximum longitudinal disturbances that could be neutralized by means of aerodynamic controls. 


\section{Computation of the correlated velocity}

The correlated velocity is defined to be a vector required by the missile at the specified position and time to achieve the position of the target for a given value of the total flight time. This velocity is usually required by the missile at burnout in order to hit a given target after free flight in the vacuum. In this paper the concept of the correlated velocity or the required velocity is extended to the flight of a SSM through the atmosphere when a thrust-terminating mechanism does not exist. The numerical procedure for the determination of the correlated velocity is developed for the passive flight of the missile in the presence of aerodynamic forces, while for the powered flight the nominal thrust versus time is included as well. The constraints for the computation of the correlated velocity are: the position of the missile coincides with that of the target $\left(\mathbf{r}=\mathbf{r}_{T}\right)$ at the end its mission, and the total time of flight is equal to the given value $t_{T f}$.

In the case of a SSM the mission is completely defined before launch and a nominal (reference) trajectory is available. The reference trajectory may be realized as a ballistic or controlled flight. The deviation of the missile from the reference trajectory is assumed to be small, so that the linear theory can be employed to generate the correlated velocity at the specified point in the space. Most of the computation for the correlated velocity is done before the mission. This concept is known as the implicit guidance.

The reference trajectory of the missile is in the vertical plane determined by the missile and target position vectors $\left(\mathbf{r}, \mathbf{r}_{T}\right)$. Motions out of the reference trajectory plane are not considered for the present. Two components of the correlated velocity should be determined and the third one in the horizontal plane is equal to zero.

In order to compute the correlated velocity, the six-degree-of-freedom mathematical model is applied and all the necessary phenomena for the unperturbed motion are included. The parameters of the missile at the beginning of the ballistic flight (at an arbitrary control point) are denoted with the subscript 0 .

\section{Computation by the ground based computer}

The position of the missile with respect to the Earth is given with cylindrical coordinates. If the initial velocity $\boldsymbol{V}_{0}$ for $t=t_{0}$ is chosen in such a way that the missile flies to the target after the time $t_{T f}$, we say that this 
velocity is equal to the correlated velocity (Fig. 1). The following equation can be written:

$$
\mathbf{r}_{T}\left(t_{T f}\right)-\mathbf{r}\left(\mathbf{r}_{0}, \mathbf{v}_{0}, t_{0}, t_{T f}\right)=0
$$

where: $\quad \mathbf{r}_{T}=\left[\begin{array}{ll}x_{T} & h_{T}\end{array}\right]^{T}, \quad \mathbf{r}_{0}=\left[\begin{array}{ll}x_{0} & h_{0}\end{array}\right]^{T}, \quad$ and $\quad \mathbf{v}_{0}=\left[\begin{array}{ll}V_{0} & \gamma_{0}\end{array}\right]^{T} \quad$ are the coordinates of the target and the missile, and the velocity of the missile on the nominal trajectory for $t=t_{0}$. Having in mind $\mathbf{v}_{0}=\mathbf{v}_{c}$, Eq. (1) may be rewritten:

$$
\mathbf{r}_{T}\left(t_{T f}\right)-\mathbf{r}\left(\mathbf{r}_{0}, \mathbf{v}_{c}, t_{0}, t_{T f}\right)=0
$$

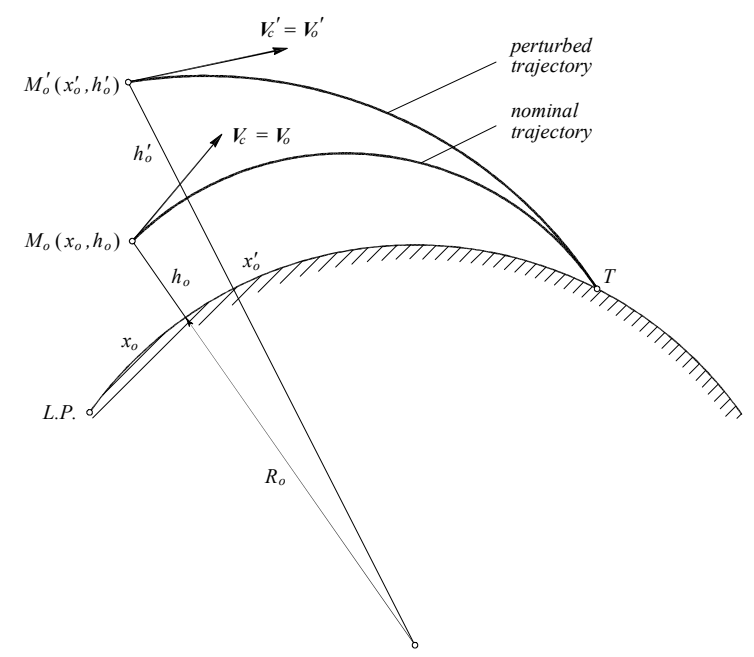

Figure 1- Correlated velocity for the reference and the perturbed trajectory.

In the case of the perturbed motion, the missile is at the position $M_{0}^{\prime}$ for $t=t_{0}^{\prime}$ (Fig. 1), where the new correlated velocity vector $\mathbf{v}_{c}^{\prime}$ can be found to satisfy

$$
\mathbf{r}_{T}\left(t_{T f}\right)-\mathbf{r}\left(\mathbf{r}_{0}^{\prime}, \mathbf{v}_{c}^{\prime}, t_{0}^{\prime}, t_{T f}\right)=0
$$

The second term in Eq. (3) can be developed into Taylor's series with respect to the reference trajectory (point $M_{0}$ )

$$
\mathbf{r}_{T}\left(t_{T f}\right)-\mathbf{r}\left(\mathbf{r}_{0}, \mathbf{v}_{c}, t_{0}, t_{T f}\right)-\left[\frac{\partial \mathbf{r}}{\partial \mathbf{r}_{0}} \Delta \mathbf{r}_{0}+\left(\frac{\partial \mathbf{r}}{\partial \mathbf{v}_{c}}\right) \Delta \mathbf{v}_{c}+\left(\frac{\partial \mathbf{r}}{\partial t_{0}}\right) \Delta t_{0}\right]=0
$$


where the partial derivatives are given for the parameters of the nominal trajectory

$$
\begin{aligned}
& \frac{\partial \mathbf{r}}{\partial \mathbf{r}_{0}}=\left[\begin{array}{ll}
\frac{\partial x}{\partial x_{0}} & \frac{\partial x}{\partial h_{0}} \\
\frac{\partial h}{\partial x_{0}} & \frac{\partial h}{\partial h_{0}}
\end{array}\right], \frac{\partial \mathbf{r}}{\partial t_{0}}=\left[\begin{array}{l}
\frac{\partial x}{\partial t_{0}} \\
\frac{\partial h}{\partial t_{0}}
\end{array}\right], \quad \frac{\partial \mathbf{r}}{\partial \mathbf{v}_{c}}=\left[\begin{array}{cc}
\frac{\partial x}{\partial V_{c}} & \frac{\partial x}{\partial \gamma_{c}} \\
\frac{\partial h}{\partial V_{c}} & \frac{\partial h}{\partial \gamma_{c}}
\end{array}\right] \\
& \Delta \mathbf{r}_{0}=\mathbf{r}_{0}^{\prime}-\mathbf{r}_{0}=\left[\begin{array}{l}
x_{0}^{\prime}-x_{0} \\
h_{0}^{\prime}-h_{0}
\end{array}\right], \Delta \mathbf{v}_{c}=\mathbf{v}_{c}^{\prime}-\mathbf{v}_{c}=\left[\begin{array}{l}
V_{c}^{\prime}-V_{c} \\
\gamma_{c}^{\prime}-\gamma_{c}
\end{array}\right] \\
& \Delta t_{0}=t_{0}^{\prime}-t_{0}
\end{aligned}
$$

The partial derivatives are approximated using the numerical procedure, for example

$$
\frac{\partial x}{\partial x_{0}}=\frac{x\left(x_{0}+\Delta x, h_{0}, V_{c}, \gamma_{c}, t_{0}, t_{T f}\right)-x\left(x_{0}, h_{0}, V_{c}, \gamma_{c}, t_{0}, t_{T f}\right)}{\Delta x}
$$

The differential correction for the correlated velocity can be found from Eq. (4) under the condition Eq. (2)

$$
\Delta \mathbf{v}_{c}=-\left(\frac{\partial \mathbf{r}}{\partial \mathbf{v}_{c}}\right)^{-1}\left(\frac{\partial \mathbf{r}}{\partial \mathbf{r}_{0}}\right) \Delta \mathbf{r}_{0}-\left(\frac{\partial r}{\partial \mathbf{v}_{c}}\right)^{-1}\left(\frac{\partial \mathbf{r}}{\partial t_{0}}\right) \Delta t_{0}
$$

Using new notations

$$
\begin{aligned}
& \frac{\partial \mathbf{v}_{c}}{\partial \mathbf{r}_{0}}=-\left(\frac{\partial \mathbf{r}}{\partial \mathbf{v}_{c}}\right)^{-1}\left(\frac{\partial \mathbf{r}}{\partial \mathbf{r}_{0}}\right) \\
& \frac{\partial \mathbf{v}_{c}}{\partial t_{0}}=-\left(\frac{\partial \mathbf{r}}{\partial \mathbf{v}_{c}}\right)^{-1}\left(\frac{\partial \mathbf{r}}{\partial t_{0}}\right)
\end{aligned}
$$

gives the formula for the differential correction of the correlated velocity

$$
\Delta \mathbf{v}_{c}=\frac{\partial \mathbf{v}_{c}}{\partial \mathbf{r}_{0}} \Delta \mathbf{r}_{0}+\frac{\partial \mathbf{v}_{c}}{\partial t_{0}} \Delta t_{0}=\left[\begin{array}{l}
\Delta V_{c} \\
\Delta \gamma_{c}
\end{array}\right]
$$

Since the correlated velocity is defined in terms of its magnitude $V_{c}$ and the flight path angle in the vertical plane $\gamma_{c}$, the Q-matrix is presented with

$$
\mathbf{Q}=\frac{\partial \mathbf{v}_{c}}{\partial \mathbf{r}_{0}}=\left[\begin{array}{ll}
\frac{\partial V_{c}}{\partial x} & \frac{\partial V_{c}}{\partial h} \\
\frac{\partial \gamma_{c}}{\partial x} & \frac{\partial \gamma_{c}}{\partial h}
\end{array}\right]
$$

The developed formula for the correction of the correlated velocity requires the Q-matrix which links a differential change in the missile position vector to a corresponding change in the correlated velocity for the fixed target 
and the constant total time of flight. The second term in Eq. (9) represents the influence of the perturbation in the initial time on the change of the correlated velocity. The correlated velocity at the point $M_{0}^{\prime}$ of the perturbed trajectory is derived on the basis of its vector at $M_{0}$ on the nominal trajectory

$$
\mathbf{v}_{c}^{\prime}=\mathbf{v}_{c}+\Delta \mathbf{v}_{c}
$$

The output data of the numerical algorithm for the correlated velocity in $n$ control points of the reference trajectory, generated by the ground based computer, are

$$
t_{i}, \mathbf{r}_{i}, \mathbf{v}_{c_{i}}, \mathbf{Q}_{i}=\left(\frac{\partial \mathbf{v}_{c}}{\partial \mathbf{r}_{0}}\right)_{i}, i=1,2,3, \ldots n
$$

where $t_{i}$ - the time of flight, $\mathbf{r}_{i}$ - the column matrix of the missile position in the vertical plane defined by cylindrical coordinates, $\mathbf{v}_{c_{i}}$ - the column matrix of the correlated velocity in the vertical plane defined with the magnitude and the angle, $\mathbf{v}_{c_{i}}=\left[\begin{array}{ll}V_{c_{i}} & \gamma_{c_{i}}\end{array}\right]^{\mathrm{T}}$, the $\mathbf{Q}_{\mathrm{i}}$ - matrix that links a differential change in the missile position to the corresponding change in the correlated velocity in the vertical plane. This set of computed data for each control point on the reference trajectory is stored in the memory of the onboard computer.

\section{Computation by the onboard computer}

The position of the missile (M) at the time $t$ is determined with $\mathbf{r}=\left[\begin{array}{ll}x & z\end{array}\right]^{\mathrm{T}}$ shown in Fig. 2. The corresponding point on the reference trajectory $\left(M^{\prime}\right)$ for the same time is determined with

$$
\mathbf{r}^{\prime}=\left[\begin{array}{ll}
x^{\prime} & z^{\prime}
\end{array}\right]^{\mathrm{T}}=\mathbf{r}^{*}(t)
$$

where the star denotes the reference trajectory and the coordinates of $M^{\prime}$ are obtained by linear interpolation of data given at the control points.

The correlated velocity at $M^{\prime}$ is also found by the linear interpolation of data in Eq. (12)

$$
\mathbf{v}_{c}^{\prime}=\left[\begin{array}{ll}
V_{c}^{\prime} & \gamma_{c}^{\prime}
\end{array}\right]^{\mathrm{T}}=\mathbf{v}_{c}^{*}(t)
$$

The position of the missile with respect to the reference trajectory is transformed in the frame that is fixed to the correlated velocity $\boldsymbol{V}_{c}^{\prime}$

$$
\mathbf{e}=\left[\begin{array}{ll}
e_{x} & e_{z}
\end{array}\right]^{\mathrm{T}}=\mathbf{C}_{v}\left(\gamma_{c}^{\prime}\right) \Delta \mathbf{r}^{\prime}
$$


where

$$
\begin{aligned}
& \Delta \mathbf{r}^{\prime}=\mathbf{r}^{\prime}-\mathbf{r}=\left[\begin{array}{ll}
x^{\prime}-x & z^{\prime}-z
\end{array}\right]^{\mathrm{T}} \\
& \mathbf{C}_{v}\left(\gamma_{c}^{\prime}\right)=\left[\begin{array}{ll}
\cos \gamma_{c}^{\prime} & -\sin \gamma_{c}^{\prime} \\
\sin \gamma_{c}^{\prime} & \cos \gamma_{c}^{\prime}
\end{array}\right]
\end{aligned}
$$

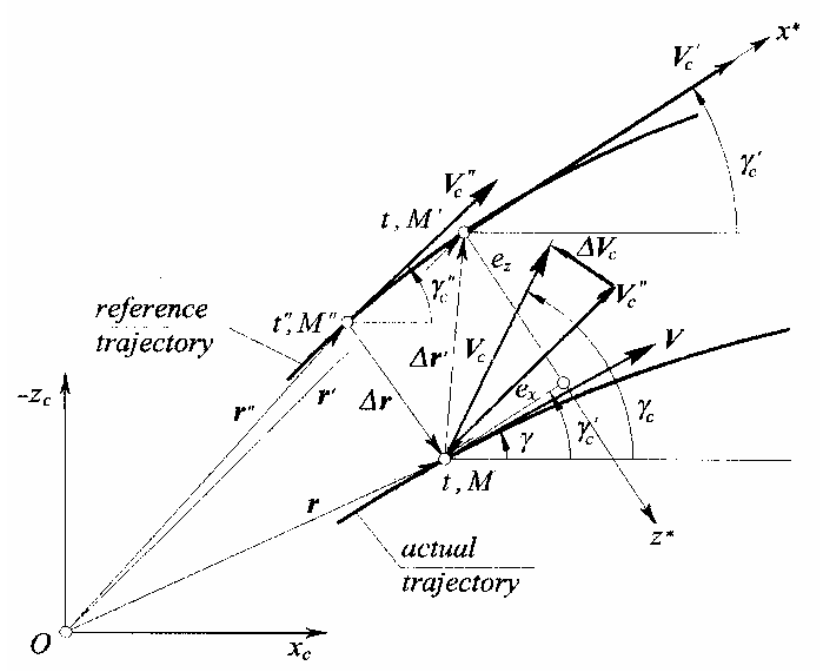

Figure 2 - Geometry of the guidance errors in the vertical plane.

If the missile is behind and below the point $M^{\prime}, e_{x}>0$ and $e_{z}>0$. Using the approximation that the point $M^{\prime \prime}\left(-e_{x}, 0\right)$ is on the reference trajectory (Fig. 2), we can determine its position in the cylindrical reference frame and the corresponding correlated velocity:

$$
\begin{aligned}
& \mathbf{r}^{\prime \prime}=\mathbf{r}^{*}\left(t^{\prime \prime}\right) \\
& \mathbf{v}_{c}^{\prime \prime}=\mathbf{v}_{c}^{*}\left(t^{\prime \prime}\right)
\end{aligned}
$$

where

$$
\begin{aligned}
& t^{\prime \prime}=t-\Delta t^{\prime \prime} \\
& \Delta t^{\prime \prime}=\frac{e_{x}}{V_{c}^{\prime}}
\end{aligned}
$$

The concept of the correlated velocity gives the following identities (see Fig. 2):

$$
\begin{aligned}
& \mathbf{r}\left(\mathbf{r}^{\prime}, \mathbf{v}_{\mathbf{c}}^{\prime}, t, t_{T f}\right)=\mathbf{r}_{T} \\
& \mathbf{r}\left(\mathbf{r}^{\prime \prime}, \mathbf{v}_{c}^{\prime \prime}, t-\Delta t^{\prime \prime}, t_{T f}\right)=\mathbf{r}\left(\mathbf{r}^{\prime \prime}, \mathbf{v}_{c}^{\prime \prime}, t, t_{T f}+\Delta t^{\prime \prime}\right)=\mathbf{r}_{T}
\end{aligned}
$$


Since $t_{T f}-\left(t-\Delta t^{\prime \prime}\right)=\left(t_{t f}+\Delta t^{\prime \prime}\right)-t$, the correlated velocity at the actual position of the missile is computed as:

$$
\begin{aligned}
& \mathbf{v}_{c}\left(\mathbf{r}, t, t_{T f}+\Delta t^{\prime \prime}, \mathbf{r}_{T}\right)=\mathbf{v}_{c}\left(\mathbf{r}^{\prime \prime}, t, t_{T f}+\Delta t^{\prime \prime}, \mathbf{r}_{T}\right)+\Delta \mathbf{v}_{c} \\
& \Delta \mathbf{v}_{c}=\mathbf{Q}\left(\mathbf{r}^{\prime \prime}, t, t_{t f}+\Delta t^{\prime \prime}, \mathbf{r}_{T}\right)\left(\mathbf{r}-\mathbf{r}^{\prime \prime}\right)
\end{aligned}
$$

The $\mathbf{Q}$-matrix is calculated using the linear interpolation of data given in Eq. (12)

$$
\mathbf{Q}\left(\mathbf{r}^{\prime \prime}, t, t_{t f}+\Delta t^{\prime \prime}, \mathbf{r}_{T}\right)=\mathbf{Q}^{*}\left(t^{\prime \prime}\right)
$$

The point $M^{\prime \prime}$ in Fig. 2 is estimated in such a way that its correlated velocity corresponds to the new value of the total time of flight $t_{t f}+\Delta t^{\prime \prime}$.

The concept of the correlated velocity can be extended to the missile which does not have a thrust-terminating mechanism, but the automatic adjustment of the total time of flight is required according to the suggestion in this paper.

The basic functions of the onboard computer in the determination of the correlated velocity vector and the deviation of the missile from the reference trajectory are shown in Fig. 3. Instead of using the missile's actual position ( $\mathbf{r}$ ), the input vector in the block diagram is obtained from SDINS ( $\tilde{\mathbf{r}})$.

The flight path angle of the correlated velocity in the horizontal plane

$$
\chi_{c}=-\tan ^{-1} \frac{y}{x_{T}-x}
$$

where $y$ is the deviation of the missile from the reference trajectory plane, $x$ the range of the missile in the cylindrical frame and $x_{T}$ is the range of the target.

\section{Guidance System Presentation}

In the case of a tactical SSM the application of the proportional navigation is adopted to the concept of the correlated velocity. The line of sight is the arc length from the missile current position $M$ to the target $T$, shown in Fig. 4 . The closing velocity is equal to the correlated velocity. If there is no perturbation, the missile flies along the arc $s$ with the correlated velocity $\boldsymbol{V}_{c}$. However, if the actual velocity is deflected from the correlated velocity, it is necessary to generate the normal acceleration that is proportional to the line-of-sight rate:

$$
f_{z d}=N^{\prime} V_{c} \dot{\lambda}
$$


where $N^{\prime}$ is the effective navigation ratio [11-12], $V_{c}$ is the closing velocity (in this case the magnitude of the correlated velocity), and $\dot{\lambda}$ is the line-of-sight rate defined as

$$
\dot{\lambda}=\frac{V \sin \left(\gamma_{c}-\gamma\right)}{s} \approx \frac{V\left(\gamma_{c}-\gamma\right)}{s}
$$

The arc length $s$ can be approximated with

$$
s \approx \frac{d s}{d t} t_{g o}=V_{c} t_{g o}
$$

where the time-to-go is

$$
t_{g o}=\left(t_{T f}+\Delta t^{\prime \prime}\right)-t
$$

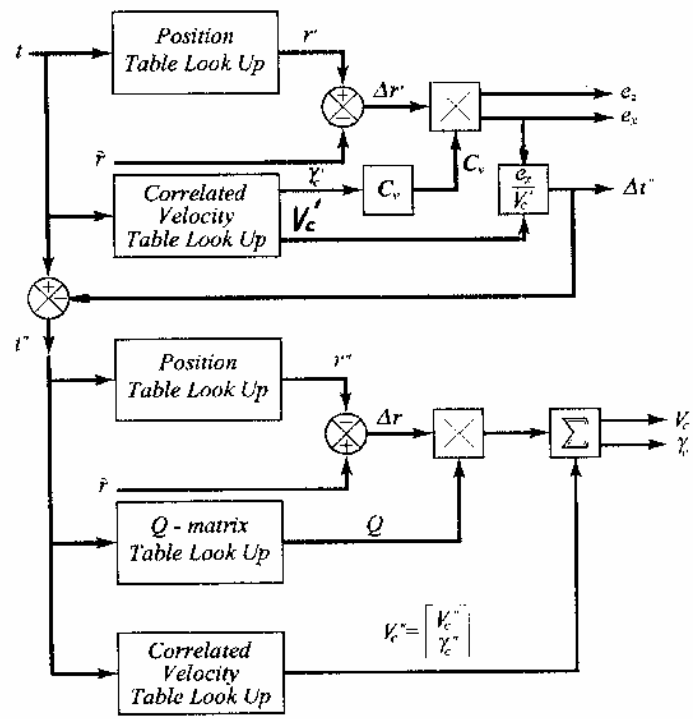

Figure 3 - Onboard computation of the correlated velocity

Substitution of Eq. (27) with Eqs. (28) and (29) into Eq. (26) yields the demanded acceleration in the vertical plane

$$
f_{z d}=\frac{N^{\prime} \tilde{V}\left(\gamma_{c}-\tilde{\gamma}\right)}{\left(t_{T f}+\Delta t^{\prime \prime}\right)-t}
$$

The demanded acceleration in the horizontal plane is given by

$$
f_{y d}=\frac{N^{\prime} \tilde{V} \cos \tilde{\gamma}\left(\chi_{c}-\tilde{\chi}\right)}{\left(t_{T f}+\Delta t^{\prime \prime}\right)-t}
$$

where the flight path angle of the correlated velocity $\chi_{c}$ is determined in Eq. (25). 


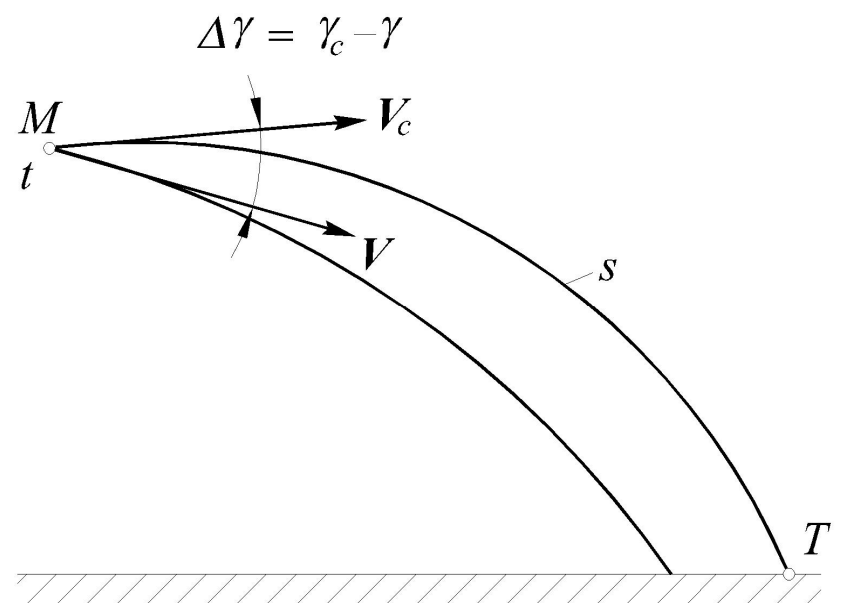

Figure 4 - Geometry of proportional navigation in the vertical plane.

\section{Control system presentation}

The control system used in a tactical SSM is a typical autopilot with three rotational channels: pitch, yaw, and roll subsystems. A roll stabilized missile is considered. The lateral autopilot receives demanded accelerations from the guidance computer, presented in the previous section, and processes them to the demanded deflections of the aerodynamic control surfaces of pitch $\left(\eta_{d}\right)$ and yaw $\left(\varsigma_{d}\right)$ channels. Both the pitch and yaw channel are composed of three loops: rate, synthetic stability and lateral acceleration. The equations for the computation of the demanded control deflections are as follows:

Pitch channel

$$
\begin{aligned}
& i_{z}^{\prime}=K_{a c}^{(1)}\left(\frac{1}{k_{a c}^{(1)}} f_{z d}-\tilde{f}_{z}\right)+\tilde{q} \\
& i_{z}=\int i_{z}^{\prime} d t \\
& \eta_{d}=K_{r}^{(1)}\left(K_{i}^{(1)} i_{z}+\tilde{q}\right)
\end{aligned}
$$

Yaw channel

$$
\begin{aligned}
& i_{y}^{\prime}=K_{a c}^{(2)}\left(-\frac{1}{k_{a c}^{(2)}} f_{y d}+\tilde{f}_{y}\right)+\tilde{r} \\
& i_{y}=\int i_{y}^{\prime} d t \\
& \zeta_{d}=K_{r}^{(2)}\left(K_{i}^{(2)} i_{y}+\tilde{r}\right)
\end{aligned}
$$


Roll channel

$$
\xi_{d}=-\left[K_{\phi}\left(\phi_{d}-\tilde{\phi}\right)-K_{p} \tilde{p}\right]
$$

The input signals are obtained from the inertial navigation system: $\tilde{f}_{z}, \tilde{f}_{y}$ - specific forces in the pitch and yaw channels, $\tilde{q}, \tilde{r}$ - the pitch and yaw rates, $\tilde{\phi}, \tilde{p}$ - the roll angle and rate. The parameters of the control system $\left(K_{a c}^{(i)}, k_{a c}^{(i)}, K_{i}^{(i)}, i=1,2\right)$ for the lateral autopilot and $K_{\phi}, K_{p}$ for the roll autopilot were determined using classical design methods presented in Refs. [13-14], for example.

The missile uses the actuator unit with four independent actuators for moving four aerodynamic surfaces. The positive deflections of the fins are shown in Fig. 5.

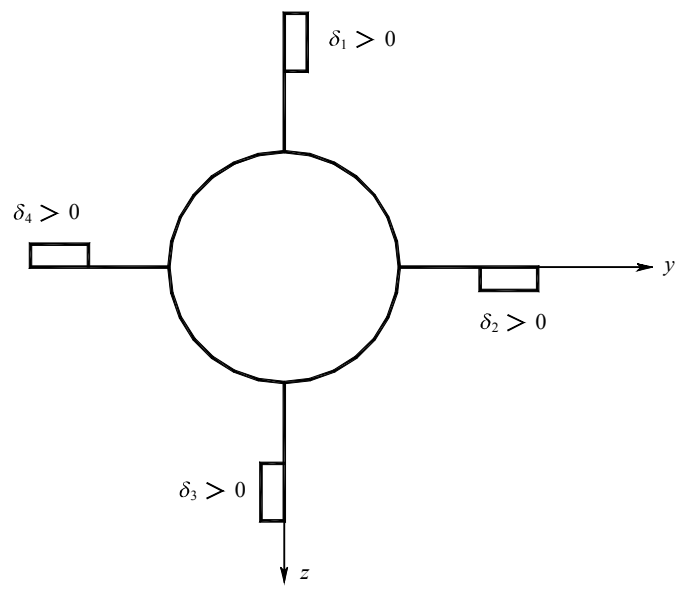

Figure 5 - Positive deflections of the fins (rear view).

The demanded values of the aileron $\left(\xi_{d}\right)$, the elevator $\left(\eta_{d}\right)$ and the rudder $\left(\varsigma_{d}\right)$ deflections are transformed to the demanded angle of each fin:

$$
\begin{aligned}
& \delta_{2 d}=\xi_{d}+\eta_{d} \\
& \delta_{4 d}=\xi_{d}-\eta_{d} \\
& \delta_{1 d}=\xi_{d}-\varsigma_{d} \\
& \delta_{3 d}=\xi_{d}+\varsigma_{d}
\end{aligned}
$$

The dynamics of each actuator is described with the second order differential equation:

$$
\ddot{\delta}_{i}+2 \mu_{a c} \omega_{a c} \dot{\delta}_{i}+\omega_{a c}^{2} \delta_{i}=\delta_{i d}, \quad i=1,2,3,4
$$


The aerodynamics coefficients were calculated in terms of the equivalent deflections of the pitch $\left(\delta_{m}\right)$, the yaw $\left(\delta_{n}\right)$, and the roll $\left(\delta_{l}\right)$ controls in the body reference frame:

$$
\begin{aligned}
& \delta_{m}=\frac{1}{2}\left(\delta_{2}-\delta_{4}\right) \\
& \delta_{n}=\frac{1}{2}\left(\delta_{3}-\delta_{1}\right) \\
& \delta_{l}=\frac{1}{4}\left(\delta_{1}+\delta_{2}+\delta_{3}+\delta_{4}\right)
\end{aligned}
$$

\section{Simulation results}

In this section, we conduct simulation studies for a tactical surface-tosurface missile to demonstrate the effectiveness of the proposed guidance law CV PNG. The rocket motor burns for $\sim 7 \mathrm{~s}$ in nominal flight conditions and imparts a total-impulse of $1400 \mathrm{kNs}$ to the missile. The missile leaves the launcher with a velocity of $56 \mathrm{~m} / \mathrm{s}$ after $0.3 \mathrm{~s}$. The maximum range of $\sim 121 \mathrm{~km}$ is achieved for the elevation angle of 55 deg after $188 \mathrm{~s}$ of flight. As a numerical example, the reference trajectory for the missile with nominal thrust vs. time was chosen to hit a ground target at the range of $100 \mathrm{~km}$ to the north from a launch point at the latitude of $45 \mathrm{deg}$. The elevation angle is equal to $\gamma_{0}=42.2332 \mathrm{deg}$, and the correction of the zero azimuth angle to compensate the Coriolis force is equal to $\Delta A_{0}=-0.28218 \mathrm{deg}$. The total time of ballistic flight is equal to $142.084 \mathrm{~s}$. The velocity of the missile is increased from $56 \mathrm{~m} / \mathrm{s}$ to $1276 \mathrm{~m} / \mathrm{s}$ for the nominal thrust. The results of the numerical simulation were obtained by running the Fortran computer program "GMTC6DOF - CV PNG" [15]. The control points for the calculation of the correlated velocity and the matrices of the influence coefficients were chosen for $2 \mathrm{~s} \leq t \leq 142 \mathrm{~s}$ with the interval of $1 \mathrm{~s}$. The total time of flight was made round to $t_{T f}=142 \mathrm{~s}$. The parameters of the control points defined in Eq. (12) are uploaded to the computer program before the numerical simulation.

The proposed proportional navigation guidance is based on the determination of the correlated velocity for the missile without a thrust terminating mechanism. The "heading error" is estimated with respect to the arc of the trajectory as a line-of-sight. The effective navigation ratio is set to the usual value of $N^{\prime}=4$. The guidance scheme was taken from Ref. [5]. In the vertical plane, the flight path steering was used until the apogee $(t=70 \mathrm{~s})$ to stabilize the angle of the correlated velocity. At the apogee, the guidance system is switched to the proportional navigation presented in this paper. In 
the horizontal plane, the line-of-sight rate is calculated using the angle of the correlated velocity given with Eq. (25). The time-to-go is constant until the apogee and it corresponds to the value of this point. After the apogee, the time-to-go is estimated using the total time of flight and the current time of flight. At the beginning of the trajectory $(t \leq 2 \mathrm{~s})$, the controlled flight stabilizes the zero demanded acceleration, and at the end of flight $(t \geq 137 \mathrm{~s})$, the missile flies with the last computed demanded acceleration.

Figures 6-9 compare trajectories, velocities, flight path angles, and control deflections for the example missile with total impulse deviation of $\pm 4 \%$ against the reference trajectory parameters. The total impulse deviations were realized by the multiplication of the nominal thrust with a constant factor of 1.04 or 0.96 . Very good results were obtained even for the unrealistic high total-impulse deviation of $\pm 4 \%$ that produces, for example, the change of the velocity $(-74,+61) \mathrm{m} / \mathrm{s}$ at $t=80 \mathrm{~s}$. If the total-impulse is increased for $+4 \%$ of the nominal value, the range miss distance is $21 \mathrm{~m}(0.2 \mathrm{mils})$. In the case of the reduced total impulse for $-4 \%$, the range miss distance is $56 \mathrm{~m}$, or 0.56 mils.

The results of the numerical simulation show that CV PNG can cope with high longitudinal disturbances without inserting additional terms that depend on the difference between the nominal and the measured velocity. The method of the computation of the correlated velocity and the adjustment of the total time of flight provide the compensation of the axial errors through a change of the flight path angle only. If the total impulse is increased, the total time of flight is corrected to a lower value in comparison with the nominal case as shown in Fig. 10. The opposite situation occurs for the reduced total-impulse.

In the case of a lower value of the total impulse, greater values of the control deflection and the angle of attack are required in comparison with the corresponding quantities when the total-impulse is increased (Fig. 9). It is easier to suppress a positive deviation of the total-impulse than a negative value of this rocket performance.

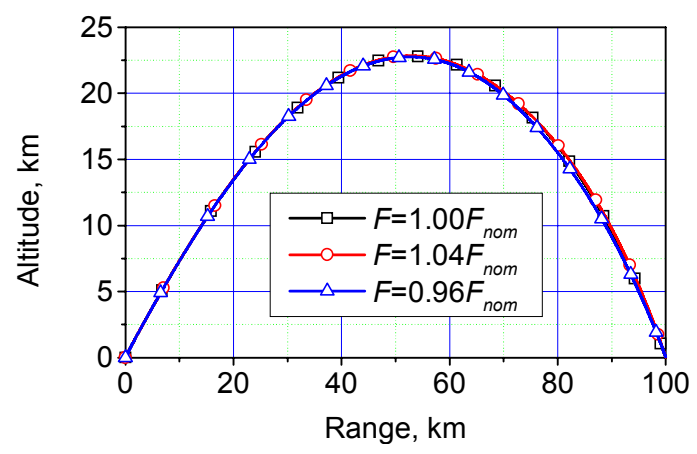

Figire 6 - Influence of a total-impulse deviation on the missile trajectory. 


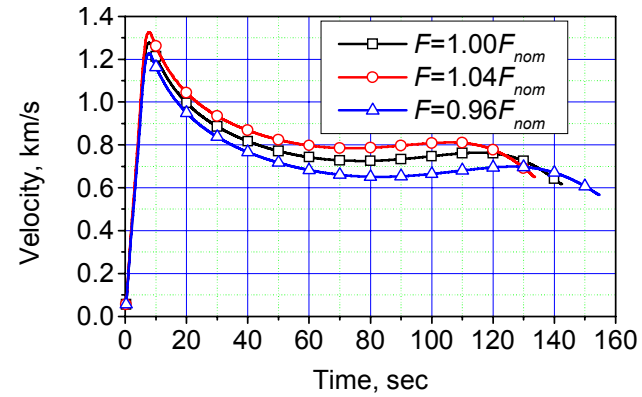

Figire 7 - Influence of a total-impulse deviation on the missile velocity

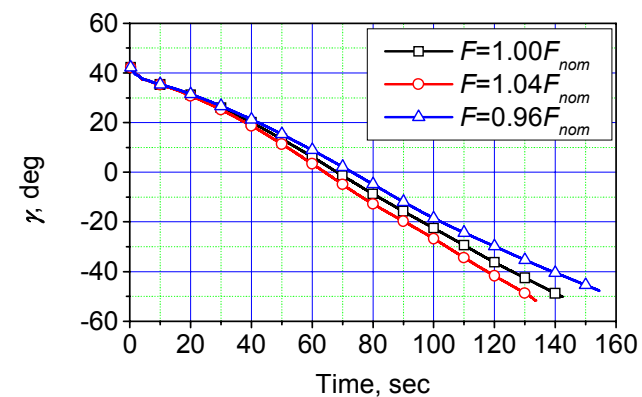

Figure 8 - Influence of a total-impulse deviation on the missile flight path angle

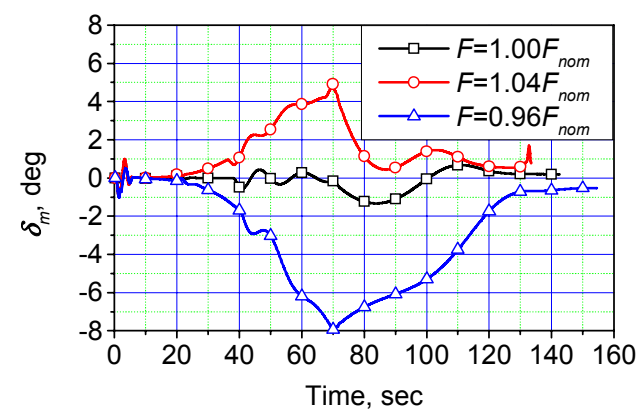

Figure 9 - Influence of a total-impulse deviation on the missile control deflection

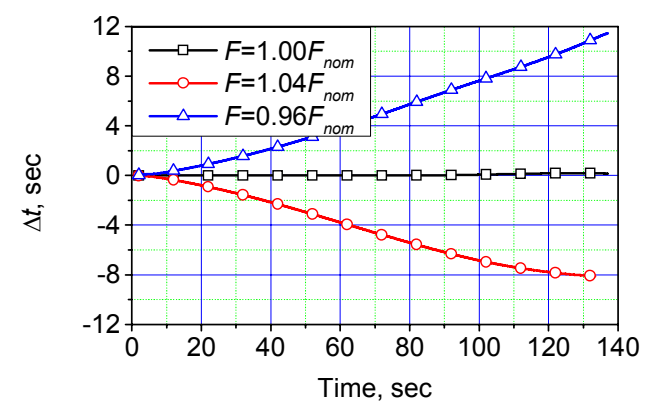

Figure 10 - Influence of a total-impulse deviation on the adjustment of the total time of flight 
Figs. 11 and 12 give the comparisons between the missile velocity parameters (magnitude and flight path angle) and the correlated velocity characteristics for both reference trajectory and computed data. There is no great difference between the computed values of the correlated velocity, $V_{c}$, and those in the control points on the reference trajectory, $V_{c}$ (ref). However, in order to compensate for the increased velocity due to a thrust deviation of $4 \%$, the diagram of the computed angle of the correlated velocity $\gamma_{c}$ is deflected from the corresponding diagram of the reference trajectory, $\gamma_{c}$ (ref), as shown in Fig. 12. The flight path angle $\gamma$ follows the diagram of the computed angle of the correlated velocity $\gamma_{c}$.

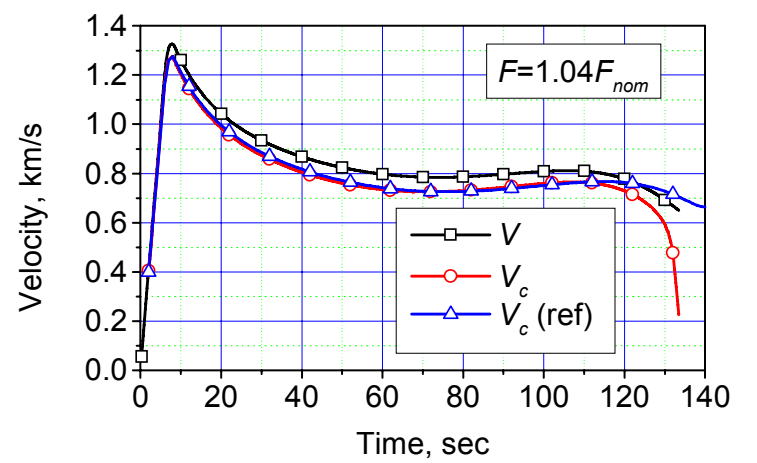

Figure 11 - Missile velocity and correlated velocity vs time.

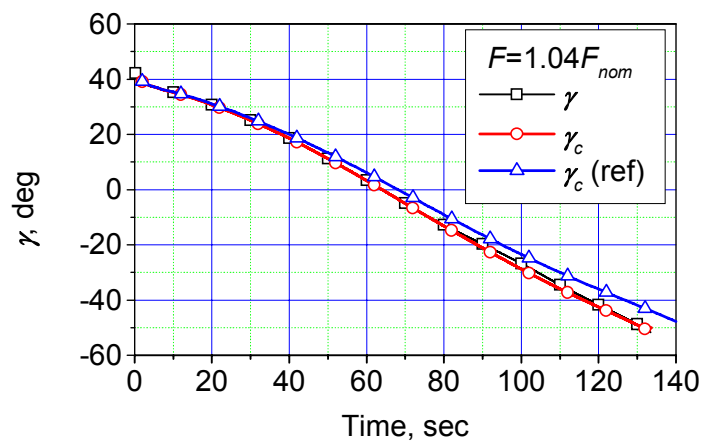

Figure 12 - Flight path and correlated velocity angles vs time.

Figs. 13-15 compare the results of the numerical simulation for CV PNG with a chosen constant total time of flight of $142 \mathrm{~s}$ against the diagrams obtained using a variable total time of flight adopted during the missile flight as shown in Fig. 10. In the case of the constant time of flight, the range miss distance is equal to $1.4 \mathrm{~km}$, or $1.4 \%$ of the nominal range. The evident difference between all parameters, except velocity, are present 
and the generated control deflection for a constant total time of flight cannot suppress the error due to the total-impulse deviation of $+4 \%$ well. For this version, there is instability in the lateral acceleration after $100 \mathrm{~s}$ of flight (Fig. 15) that may be the reason of the increased range miss distance.

The comparison of the results given in Figs. 13-15 proves that it is necessary to adopt the total time of flight in order to achieve a high accuracy of SSM.

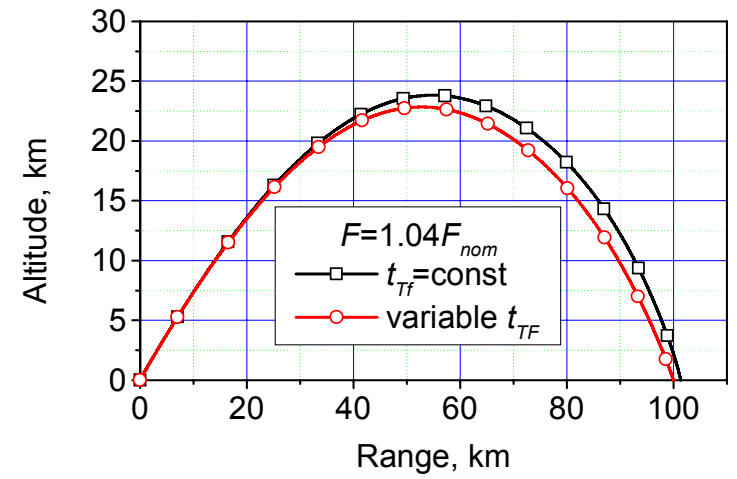

Figure 13 - Influence of the total time of flight on the trajectory.

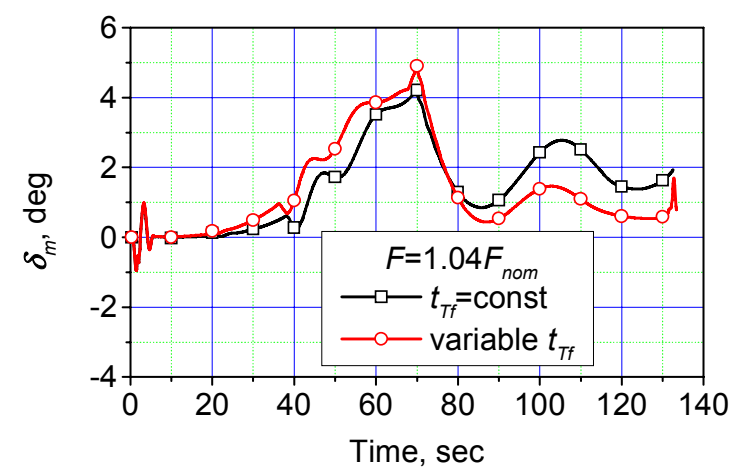

Figure 14 - Influence of the total time of flight on the control deflection.

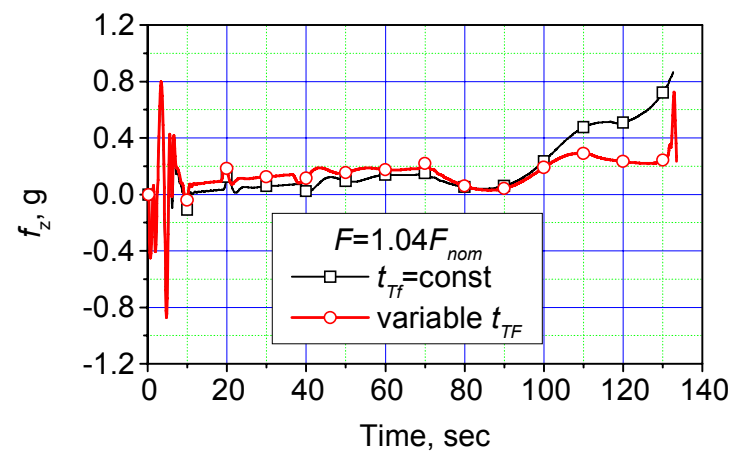

Figure 15 - Influence of the total time of flight on the lateral acceleration. 
Fig. 16 compares the impact points at a range of $100 \mathrm{~km}$ for the missile with an ideal rocket motor, and with a thrust magnitude deviation and misalignment. The instrument errors are described with the scale factor errors and the fixed bias: $1 \sigma$ of the scale factor error for both gyros and accelerometers is $0.1 \%, 1 \sigma$ of the fixed bias for gyros is $5 \mathrm{deg} / \mathrm{hour}$, and $1 \sigma$ of the fixed bias for accelerometers is $0.5 \mathrm{mg}$. The standard deviations of the thrust for the actual rocket motor are: $\sigma_{F}=2 \%$ for the thrust magnitude, and $\sigma_{\varepsilon}=2 \mathrm{mrad}$ for the thrust misalignment. All random variables are independent Gaussian random variables, except the angle of the plane of thrust misalignment that has a uniform distribution in the interval of $[0,2 \pi]$ relative to the body frame. A Monte Carlo simulation was applied on a sample size of 42 trajectories. The probable range and lateral dispersions for the missile with an ideal rocket motor are 1.25 mils and 0.41 mils, respectively. Approximately, the same parameters for the missile with simulation of the actual rocket motor were obtained. The comparison of the impact point dispersions show that the disturbances due to tolerances of a rocket motor (magnitude deviation and thrust misalignment) were suppressed with CV PNG very well. Hence, the accuracy of the missile with CV PNG depends on the accuracy of the applied instruments only.

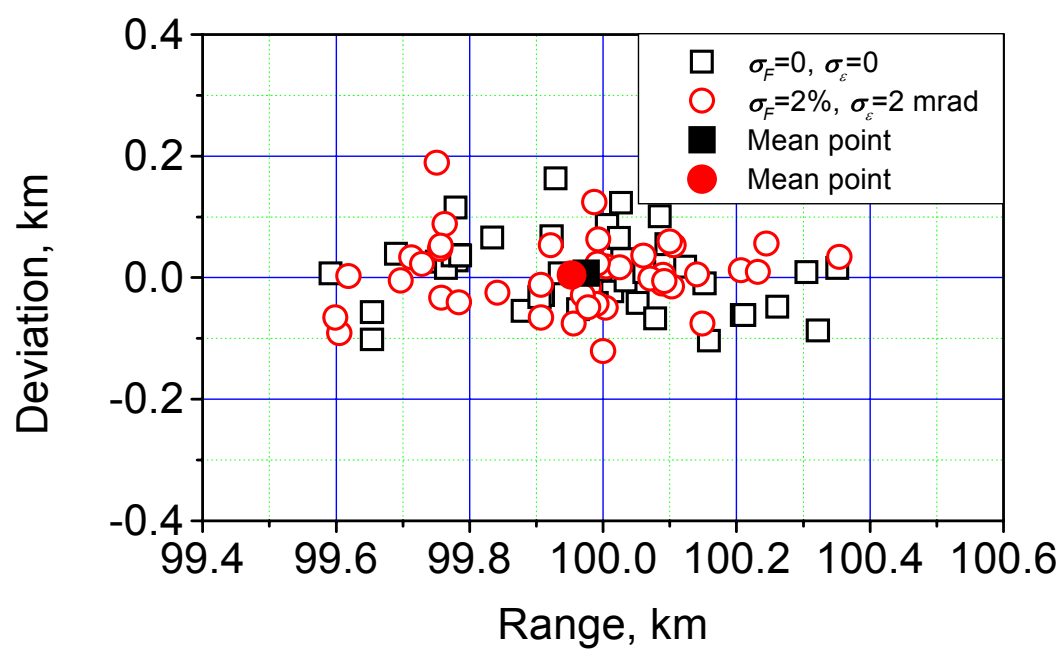

Figure 16 - Impact point dispersion of the missile. 


\section{Conclusions}

The ability of the guidance law CV PNG to improve dispersion performances of SSM was demonstrated using a six-degree-of-freedom numerical simulation. The guidance errors were generated using the "measured" data from SDINS and the computation of the correlated velocity. The concept of the correlated velocity was extended to the application for a tactical surface-to-surface missile with no thrust terminating mechanism. The adjustment of the total time of flight was included in the numerical procedure for the determination of the correlated velocity.

The guidance law CV PNG can cope with lateral disturbances such as thrust misalignment and side wind successfully. The probable lateral dispersion is about 0.4 mils and it depends mainly on instruments errors. The probable range dispersion is less than 1.3 mils of the nominal range.

\section{References}

[1] Gregoriou, G., CEP Calculation for a Rocket with Different Control System, J. Guidance, Vol. 11, No. 3, 1988, pp. 193-198.

[2] Jitpraphai, T., and Costello, M., Dispersion Reduction of a Direct Fire Rocket Using Lateral Pulse Jets, Journal of Spacecraft and Rockets, Vol. 38, No. 6,2001, pp. 929-936.

[3] Zhao, H., Wang, F., and Lin, Q., The Investigation about Using Different Guidance Laws on Improving Impact Point Deviation of a Rocket, $22^{\text {nd }}$ International Symposium on Ballistics, Vol. 1, National Defense Industrial Association, USA with International Ballistics Committee, Vancouver BC, Canada, 2005, pp. 81-87.

[4] Jitraphai, T., Burchett, B., and Costello, M., A Comparison of Different Guidance Schemes for a Direct Fire Rocket With a Pulse Jet Control Mechanism, Oregon State University, Corvallis, 2002.

[5] Gamble, A. E., and Jenkins, P.N., Low Cost Guidance for the Multiple Launch Rocket System (MLRS) Artillery Rocket, IEEE AES Systems Magazine, January 2001, pp. 33-39.

[6] Ćuk, D., Influence of Range Extension on Dynamic Stability of Artillery Rockets with Wrap Around Fins, Military Technical Courier/Vojnotehnički glasnik, Vol. 55, No. 3, pp. 296-307, Ministry of Defence, Belgrade, Serbia, 2007.

[7] Morrison, Ph. H., and Amberntson, D. S., Guidance and Control of a Cannon-Launched Guided Projectile, J. Spacecraft, Vol. 14, No. 6, pp. 328-334.

[8] Ćuk, D., Trajectory Correction of Gyroscopic Stabilized Projectile Using Proportional Navigation, Military Technical Courier/Vojnotehnički glasnik, Vol. 58, No. 1, pp. 13-32, Ministry of Defence, Belgrade, Serbia, 2010.

[9] Siouris, G. M., Missile Guidance and Control Systems, Springer, New York, 2004

[10] Cuk, D., Choice of the Rotational Factor of the Thrust Vector for the Ballistic Missile With Lambert Guidance, Military Technical Courier/ Vojnotehnički glasnik, Vol. 57, No. 2, pp. 133-146, Ministry of Defence, Belgrade, Serbia, 2009. 
[11] Garnel, P., Guided Weapon Control Systems, $2^{\text {nd }}$ ed., Pergamon, New York, 1980

[12] Nesline, F. W., and Zarchan, P., A New Look at Classical vs Modern Homing Missile Guidance, J. Guidance and Control, Vol. 4, No. 1, 1981, pp. 78-85.

[13] Nesline, F. W. and Nesline, M. L., How Autopilot Requirements Constrain the Aerodynamic Design of Homing Missiles, American Control Conference Proceedings, June 1984, pp. 716-730.

[14] Ćuk, D., Mandić, S., Comparison of Different Lateral Acceleration Autopilots for a Surface-to-Surface Missile, Military Technical Courier/Vojnotehnički glasnik, Vol. 59, No. 3, pp. 7-28, Ministry of Defence, Belgrade, Serbia, 2011.

[15] Ćuk, D., The program Guided Missile Trajectory Calculation by using 6 DOF Model (GMTC6DOF) and the method Correlated Velocity Proportional Navigation Guidance (CV PNG), 2007, cukd@eunet.rs.

NOVI ZAKON VOĐENJA ZA TAKTIČKU RAKETU ZEMLJA-ZEMLJA

OBLAST: vazduhoplovstvo, raketna i svemirska tehnologija

VRSTA ČLANKA: originalni naučni rad

Sažetak

Savremene rakete zemlja-zemlja, opremljene besplatformnim sistemom inercijalne navigacije, postižu veoma dobru tačnost u poređenju sa nevođenim raketama. Verovatno odstupanje po dometu zavisi uglavnom od instrumentalnih grešaka i poremećaja u pravcu uzdužne ose rakete kao što su devijacija totalnog impulsa raketnog motora, razlike u procenjenim $i$ stvarnim vrednostima aksijalne sile $i$ čeoni vetar. Ovaj rad daje proširenje koncepta korelisane brzine na rakete zemljazemlja koje nemaju mehanizam za prekid rada raketnog motora. Sračunati parametri korelisane brzine smešteni su u memoriju kompjutera za vođenje na raketi. Na osnovu koncepta korelisane brzine, predložena je modifikacija proporcionalne navigacije koja obuhvata podešavanje vremena do susreta rakete i cilja. Pokazano je da novi zakon vođenja može uspešno da kompenzira uzdužne poremećaje različitog nivoa. Efikasnost predložene metode vođenja potvrđena je preko sračunatih verovatnih odstupanja po dometu i pravcu za očekujuće poremećaje u sistemu vođenja.

Uvod

Nevođene rakete imaju veliko rasturanje padnih tačaka na dometima preko $50 \mathrm{~km}$. Uz primenu savremenih tehnologija ova kategorija raketa može dostići tačnost $1 \%$ od dometa. Međutim, ova performansa nije prihvatjjiva čak ni za rakete vatrene podrške. Značajno poboljšanje tačnosti postiže se ugradnjom besplatformnog sistema inercijalne navigacije (SDINS) i konstrukcijom odgovarajućeg sistema vođenja i upravljanja rakete. Predmet ovoga rada je prikaz novog zakona vođenja za taktičke ra- 
kete zemlja-zemlja (Z-Z). Za razliku od objavljenih radova u kojima se izučavaju algoritmi proračuna korelisane brzine za rakete koje najveći deo putanje realizuju u bezvazdušnom prostoru, u ovom radu daje se metoda proračuna korelisane brzine za rakete bez uređaja za prekid rada raketnog motora i pri letu kroz atmosferu.

Proračun korelisane brzine

Korelisana brzina se definiše kao vektorska veličina koju raketa treba da ima u proizvoljnoj tački da bi dostigla cilj za zadato vreme. Prikazani proračun korelisane brzine ima dve specifičnosti: 1) raketa nema uređaj za prekid rada raketnog motora, pa se proračun obavlja i za aktivnu i pasivnu fazu leta, i 2) proračun putanje u prisustvu sile potiska i aerodinamičkih sila i momenata vrši se pomoću modela „šest stepeni slobode kretanja" (6-DOF). Numerički podaci o korelisanoj brzini rakete generišu se u određenom broju kontrolnih tačaka na referentnoj putanji i predstavljaju osnovu za tzv. implicitno vođenje.

Proračun pomoću zemaljskog kompjutera

Budući da je misija rakete $Z-Z$ u potpunosti definisana neposredno pre lansiranja, kao referentna putanja bira se balistička putanja sa elementima gađanja koji omogućavaju pogodak cilja u mirnoj atmosferi bez bilo kakvih poremećaja. Dat je postupak proračuna Q-matrice koja određuje priraštaj korelisane brzine zbog diferencijalne promene vektora položaja rakete u odnosu na referentnu putanju. Definisani su svi potrebni ulazni podaci o referentnoj putanji i korelisanoj brzini koji se unose u memoriju kompjutera ugrađenog u raketu.

Proračun pomoću kompjutera na raketi

Dat je postupak proračuna korelisane brzine u realnom vremenu polazeći od odstupanja rakete od referentne putanje. Pokazano je da se koncept korelisane brzine može proširiti i na raketu bez uređaja za prekid rada raketnog motora, s tim da se u toku leta vrši podešavanje ukupnog vremena leta prema metodi datoj u ovom radu.

\section{Prikaz sistema vođenja}

Kao metoda vođenja usvojena je proporcionalna navigacija s tim što „liniju viziranja cilja" predstavlja putanja po kojoj se raketa kreće korelisanom brzinom od proizvoljnog položaja do željenog cilja. Greška vođenja je ugaona brzina "linije viziranja cilja" koja se određuje na osnovu ugaonog odstupanja stvarne brzine, određene navigacionim algoritmom SDINS-a, od korelisane brzine rakete. Ova metoda vođenja nazvana je proporcionalna navigacija na osnovu korelisane brzine rakete (CV PNG).

Prikaz sistema upravljanja

Kao sistem upravljanja raketom primenjen je klasičan trokanalni autopilot sa stabilizacijom propinjanja, skretanja $i$ valjanja. Kanali propinjanja i skretanja dobijaju zahtevano normalno ubrzanje na osnovu proračuna po metodi CV PNG. Imaju tri povratne veze: po ugaonoj brzini, integra- 
lu ugaone brzine i normalnom ubrzanju. Raketa poseduje četiri nezavisna aktuatora aerodinamičkih upravljačkih krila pomoću kojih se realizuju komande propinjanja, skretanja i valjanja.

Rezultati simulacije

Rezultati numeričke simulacije po modelu „6-DOF“ dobijeni su pomoću fortranskog programa „GMTC6DOF - CV PNG“. Korišćena je sledeća šema vođenja: u vertikalnoj ravni do temena putanje primenjeno je upravljanje pravcem vektora brzine, a od temena metoda CV PNG; u horizontalnoj ravni koristi se proporcionalna navigacija, $s$ tim što je do temena putanje vreme do susreta cilja konstantno i odgovara ovoj tački na putanji, a od temena putanje menja se u skladu sa promenom tekućeg vremena leta rakete. Predloženi zakon vođenja CV PNG uspešno kompenzuje ekstremno odstupanje totalnog impulsa raketnog motora od $\pm 4 \%$. Data je komparativna analiza parametara vođenja za varijante sa korekcijom i bez korekcije ukupnog vremena leta u uslovima ekstremnog odstupanja totalnog impulsa. Primenom Monte Karlo simulacije analiziran je uticaj instrumentalnih grešaka SDINS-a (greška skaliranja i sistematska greška brzinskih žiroskopa i akcelerometara), kao i slučajnog odstupanja sile potiska (intenziteta i ekscentriciteta) na verovatna odstupanja po dometu i pravcu.

Zaključak

U radu je predložena nova metoda vođenja za rakete zemlja-zemlja koja se zasniva na modifikaciji proporcionalne navigacije i korišćenju podataka o korelisanoj brzini. Koncept korelisane brzine je proširen na taktičke rakete Z-Z koje nemaju uređaj za prekid rada raketnog motora, a let realizuju u uslovima u kojima su bitne aerodinamičke sile i momenti. Pokazano je da je predložena metoda vođenja efikasna i pri ekstremno velikom odstupanju totalnog impulsa raketnog motora. Verovatna odstupanja po pravcu i dometu višestruko su smanjena u odnosu na iste veličine kod nevođenih raketa $Z-Z$.

Ključne reči: zakon vođenja, raketa zemlja-zemlja, korelisana brzina, proporcionalna navigacija, model „šest stepeni slobode kretanja“.

Datum prijema članka: 11. 07. 2011.

Datum dostavljanja ispravki rukopisa: 10. 08. 2011.

Datum konačnog prihvatanja članka za objavljivanje: 12. 08. 2011. 